\title{
Removal of harmful algal cells (Karenia brevis) and toxins from seawater culture by clay flocculation
}

\author{
Richard H. Pierce ${ }^{a, b, *}$, Michael S. Henry ${ }^{a, b}$, Christopher J. Higham ${ }^{\text {a,b }}$, \\ Patricia Blum $^{\mathrm{a}}$, Mario R. Sengco ${ }^{\mathrm{a}, \mathrm{b}}$, Donald M. Anderson ${ }^{\mathrm{b}}$ \\ ${ }^{a}$ Mote Marine Laboratory, 1600 Ken Thompson Parkway, Sarasota, FL 34236, USA \\ ${ }^{\mathrm{b}}$ Biology Department, Woods Hole Oceanographic Institution, Woods Hole, MA 02543, USA
}

Received 12 August 2003; received in revised form 7 September 2003; accepted 25 September 2003

\begin{abstract}
Harmful algal blooms (HABs) occur worldwide causing serious threat to marine life, and to public health through seafood-borne illnesses and exposure to toxin-containing marine aerosol. This study was undertaken to assess the ability of phosphatic clay to remove the toxic dinoflagellate, Karenia brevis, and the potent neurotoxins (brevetoxins) produced by this species. Results showed that the addition of an aqueous slurry of $0.75 \mathrm{~g}$ (dry weight) clay to $31 \mathrm{of}$ K. brevis culture, containing $5 \times 10^{6}$ and $10 \times 10^{6}$ cells $/$, removed $97 \pm 4 \%$ of brevetoxins from the water column within $4 \mathrm{~h}$ after the addition of clay. Clay flocculation of extra-cellular brevetoxins, released from cells ruptured (lyzed) by ultrasonication, removed $70 \pm 10 \%$ of the toxins. Addition of the chemical flocculant, polyaluminum chloride (PAC), removed all of the extra-cellular toxins. A 14 day study was undertaken to observe the fate of brevetoxins associated with clay flocculation of viable K. brevis cells. At $24 \mathrm{~h}$ following the clay addition, $90 \pm 18 \%$ of the toxins were removed from the water column, along with $85 \pm 4 \%$ of the cells. The toxin content of clay diminished from $208 \pm 13 \mu \mathrm{g}$ at Day 1, to $121 \pm 21 \mu \mathrm{g}$ at Day 14, indicating that the phosphatic clay retained about $58 \%$ of the toxins throughout the 14-day period. These studies showed the utility of natural clay as a means of reducing adverse effects from HABs, including removal of dissolved toxins, in the water column, although considerable work clearly remains before this approach can be used on natural blooms in open waters.
\end{abstract}

(c) 2004 Elsevier B.V. All rights reserved.

Keywords: Harmful algal blooms (HABs); Red tide; Karenia brevis; Brevetoxins; Clay flocculation; Mitigation

\section{Introduction}

Harmful algal blooms (HABs) occur throughout the world as a result of high concentrations of marine algae, many of which produce potent toxins (Smayda, 1990; Anderson and Garrison, 1997). The Florida red tide is a recurring HAB that is prevalent in the Gulf of

\footnotetext{
* Corresponding author. Tel.: +1-941-388-4441; fax: +1-941-388-4312.

E-mail address: rich@mote.org (R.H. Pierce).
}

Mexico and periodically along the US Atlantic coast (Tester and Steidinger, 1997). The causative organism, Karenia brevis (formerly, Gymnodinium breve, Davis) (Duagbjerg et al., 2001), produces a suite of as many as 10 polyether neurotoxins known as brevetoxins (Poli et al., 1986; Shimizu et al., 1990; Baden et al., 1995). As they are produced within the cell, brevetoxins occur as intracellular toxins. However, upon rupture or lysing of the cells, the toxins can then be released into the water column as extracellular toxins (Steidinger and Baden, 1983; Pierce et al., 2001). Brevetoxins 
cause massive fish kills that litter miles of beaches and estuarine shorelines with dead and decaying fish. In addition, filter-feeding shellfish accumulate the alga and toxins resulting in neurotoxic shellfish poisoning (NSP) in human consumers (Steidinger and Baden, 1983; Baden et al., 1995; Dickey et al., 1999). Brevetoxins in seawater also become incorporated into marine aerosol through bubble-mediated transport, causing severe respiratory irritation to people and other mammals along the shore (Pierce et al., 1990; Pierce et al., 2003).

The significant adverse impacts of HABs on public health, economics and natural resources have led to intensive monitoring programs to detect the presence of HABs. Although such programs are essential for alerting the public to potential dangers, the severity and growing threat of HABs and their impacts could justify bloom mitigation and direct control as approaches for protecting public health and the marine ecosystem (Anderson, 1997; Boesch et al., 1997).

A promising strategy for controlling HABs is the application of natural clays over the surface of a bloom to remove the algae from the water column through co-flocculation and sedimentation (Anderson, 1997). This method has been used successfully in the field in Japan (Shirota, 1989) and South Korea (Na et al., 1997) to control outbreaks of fish-killing marine algae, and to minimize the impact of blooms on vital mariculture resources. Additional research into clay control of local bloom-forming species has also been conducted in China (Yu et al., 1994, 1995) and the United States (Sengco et al., 2001), demonstrating the effectiveness of clay and the combination of clay with chemical flocculants such as polyaluminum chloride (PAC), to remove a number of algal species from the water column.

Having demonstrated the effectiveness of phosphatic clay in removing $K$. brevis from suspension in laboratory studies (Sengco et al., 2001), the focus of this study was to investigate whether the same clay and clay-flocculant combination (phosphatic clay + PAC) could remove both intra- and extra-cellular brevetoxins (Pierce et al., 2001). Due to their hydrophobic nature, a common method for recovering brevetoxins from seawater is by adsorption of toxins onto hydrophobic substances, either in the form of small particles, or as a matrix within a filter disk (Pierce et al., 1992; Pierce and Kirkpatrick, 2001). The high surface area and charge properties of clay suggest that clay could be effective for adsorbing hydrophobic, extra-cellular brevetoxin molecules from water, in addition to the removal of intra-cellular brevetoxins within clay-flocculated algal cells. These studies were performed under controlled laboratory conditions to determine the most effective conditions for the use of phosphatic clay and clay with PAC for removal of brevetoxins from seawater. Finally, experiments were conducted to determine the fate of brevetoxins associated with the clay floc. This aspect of the study was motivated by the fact that the clay mitigation strategy does introduce environmental concerns, such as those associated with the deposition and potential resuspension of toxic clay/cell flocs in the benthos, with corresponding impacts on benthic communities.

\section{Methods}

Cultures of $K$. brevis Davis (Wilson isolate, CCMP 718) were obtained from the phytoplankton culture facilities at Mote Marine Laboratory, and maintained under wide spectrum fluorescent radiation in a $12 \mathrm{~h}$ light: $12 \mathrm{~h}$ dark cycle at room temperature $\left(25^{\circ} \mathrm{C}\right)$. The experimental cultures of $K$. brevis cells were prepared in 41 Pyrex beakers containing seawater growth medium (36 ppt enriched with L1 medium) (Guillard and Hargraves, 1993), which were inoculated with exponentially growing culture to achieve 31 of the experimental $K$. brevis concentration. The cell concentrations used for this experiment were between $5 \times 10^{6}$ and $10 \times 10^{6}$ cells/l, representing concentrations found during natural blooms along the Florida Gulf coast (Tester and Steidinger, 1997). Immediately following inoculation of each experimental culture, $10 \mathrm{ml}$ aliquots were collected and preserved with Utermöhl's solution (0.05 ml/l) (Guillard, 1973) and the cell counts verified by microscopic enumeration at $100 \times$ magnification using an inverted microscope.

Flocculation experiments were performed in triplicate, using 31 of experimental culture, with the addition of phosphatic clay (IMC-P2) (International Mining Corporation (IMC), Bartow, FL) following the work of Sengco et al. (2001). The flocculation studies encompassed two time series, a short-term $4 \mathrm{~h}$ flocculation study and a long-term 14-day study, as described below. Phosphatic clays are the unused or waste portion of phosphate rock (carbonate-fluorapatite) and 
contain particles $\leq 125 \mu \mathrm{m}$, although $>70 \%$ of the particles are in the size range of silt and clays (Barwood, 1982). For IMC-P2, 99.4\% of the particles were $<2 \mu \mathrm{m}$. IMC-P2 includes the following minerals in decreasing amounts: smectite, carbonate fluorapatite, palygorskite (attapulgite), mica, interstratified clays, kaolinite, quartz, wavellite, crandallite, dolomite, calcite, feldspar, millisite, and trace amounts of heavy metals (Bromwell, 1982). IMC-P2 phosphatic clay was provided as a concentrated slurry $(16.7 \%(\mathrm{~m} / \mathrm{m})$ solid content, or $178 \mathrm{~g} / \mathrm{l})$ in freshwater. The percent solid content of the slurry was determined by drying a known mass of wet clay overnight in a laboratory oven $\left(80^{\circ} \mathrm{C}\right)$, then dividing the dry weight by the wet weight. Sengco et al. (2001) found the most efficient concentration of clay slurry to be between 0.25 and $0.5 \mathrm{~g}$ clay/l final concentration. For these experiments, a concentrated clay slurry was prepared by suspending $0.75 \mathrm{~g}$ clay (dry weight) into $75 \mathrm{ml}$ of distilled/deionized (D/DI) water which was then evenly dispersed over the surface of each 31 experimental culture. Control cultures received a $75 \mathrm{ml}$ dose of D/DI water only (no clay added). The effect of the flocculant PAC was tested by adding an aqueous slurry of PAC (Cytec Industries) to an additional set of cultures, resulting in $4.2 \mathrm{mg} \mathrm{PAC} / \mathrm{l}$ culture. The PAC was allowed to work for $30 \mathrm{~min}$ and then $0.25 \mathrm{~g} / \mathrm{l}$ clay was added. An additional set of clay and clay + PAC flocculation studies was performed using 0.51 of lyzed culture. Lyzed culture was prepared by subjecting 11 aliquots of the K. brevis culture to ultrasonic disruption for 5-7 min using a Vibra-cell VC-500 ultrasonic probe (Sonics and Materials, Danbury CT). Verification of cell lysing was provided by microscopic examination.

\subsection{Short-term (4 h) flocculation study}

The removal efficiency of $K$. brevis and brevetoxins from seawater was determined by cell counts and analysis of toxins in the water and in association with the settled clay, that was observed to settle to the bottom of the container with in 3-4h after the addition of clay. Brevetoxin recovery from $K$. brevis cultures was initiated by vacuum filtration through glass microfiber filters (GF/D, Whatman, Clifton, NJ) to remove suspended particles and allow extra-cellular toxins to pass through the filter with the filtrate. Intra-cellular breve- toxins were recovered by lysing viable $K$. brevis cells remaining on the filter by soaking for $3 \mathrm{~min}$ in D/DI water and then rinsed several times under vacuum, releasing the remaining toxins onto the filtrate. The toxins were recovered from the filtrate by elution through a C-18 solid phase extraction disc (Spec 47 C-18AR, Ansys Diagnostics Inc., Lake Forest, CA) and eluted from the C-18 disc with $20 \mathrm{ml}$ methanol under gentle vacuum. The methanol was reduced in volume on a rotary-evaporation unit until dry and brought to a final volume of $3 \mathrm{ml}$ in methanol for high performance liquid chromatography (HPLC) analysis. The GF/D filters were also extracted to insure recovery of all brevetoxins.

After settling for up to $4 \mathrm{~h}, 10 \mathrm{ml}$ aliquots were taken from the overlying water in each container and preserved with Utermöhl solution for cell counts. Then, the clarified liquid above the settled clay was collected with careful siphoning to avoid resuspension of the clay floc. The exact volume of water collected was measured and then extracted by elution through a C-18 disk as above. The wet clay samples were allowed to compact (or dewater) overnight at $4{ }^{\circ} \mathrm{C}$ to further expel interstitial water from the floc layer. The water above the clay layer was decanted and each wet clay sample was then centrifuged at $2400 \mathrm{rpm}$ for $4 \mathrm{~min}$ to remove remaining water. The decanted water and supernatant samples were extracted to see if any significant amount of toxin remained. Brevetoxins were recovered from the clay pellet by ultrasonic agitation in acetone, using the ultrasonic probe as described above for cell lysing. Clay and acetone were separated by centrifugation and the procedure was repeated three times or until the solvent layer was colorless. The acetone was evaporated and the residue reconstituted in $3 \mathrm{ml}$ of methanol for high-performance liquid chromatography with detection by mass spectrometry (HPLC-MS) analysis.

Brevetoxin analyses were performed using a Shimadzu HPLC (Colombia, MD) with a $25 \mathrm{~cm} \times 0.5 \mathrm{~cm}$ OD5 reverse-phase $\mathrm{SiO}_{2}-\mathrm{C} 18$ column (Burdick and Jackson Muskegon, MI) and an isocratic mobile phase of $85: 15$ methanol: water at $1 \mathrm{ml} / \mathrm{min}$, coupled with a Shimadzu model SPDM6A Diode-array detector, with quantitation at $215 \mathrm{~nm}$. The instrument was calibrated with a standard brevetoxin mix containing PbTx-2 and PbTx-3, obtained from Dr. Dan Baden, UNC Wilmington, NC, to verify qualitative retention times and quantitative UV-detector response for the 
toxins. Toxin nomenclature followed the protocol of Poli et al. (1986).

\subsection{Long-term (14 day) flocculation study}

The fate of brevetoxins associated with the clay floc was investigated over time using diluted $K$. brevis cultures in 41 beakers with the addition of clay slurry as described above. For this study, 24, 41 beakers were filled with 31 of $K$. brevis culture. Eighteen cultures received $0.25 \mathrm{~g}$ clay/l and six cultures were maintained as controls with no clay added. The cell counts and toxin concentrations were determined for triplicate sets of cultures prior to clay addition and on Days 1, 3, 6, 10 and 14 after clay flocculation. The initial cell counts and toxin concentrations were determined on three control cultures at the outset of the experiment. On Days 1, 3, 6 and 10, three experimental cultures were separated into the settled clay and overlying water fractions and analyzed for brevetoxin content as previously described. On Day 14 , the remaining three experimental cultures and the three controls were analyzed.

\section{Results}

\subsection{Short-term (4 h) flocculation study}

Results of brevetoxin removal from water at 3-4h after the addition of clay and clay + PAC are summa- rized in Table 1. For the cultures used in this study, only PbTx-2 was detected in sufficient concentrations for quantification by HPLC-UV (LOD $>0.05 \mu \mathrm{g} / \mathrm{l}$ ). A comparison of the amount of PbTx-2 associated with the flocculated clay with the amount of PbTx-2 remaining in the water shows that the clay removed between 92 and $100 \%$ of brevetoxin associated with viable $K$. brevis cells (intra-cellular toxins). The addition of PAC with clay provided $99 \pm 3 \%$ removal of toxin. The removal of extra-cellular toxin (released from $K$. brevis cells by ultrasonication) by clay was not as efficient as for the intra-cellular toxin. Two sets of triplicate experiments exhibited $74 \pm 8$ and $65 \pm 10 \%$ removal with clay only. The addition of the flocculant, PAC, however, did enhance the removal of extra-cellular brevetoxin from the water, resulting in $100 \%$ of the brevetoxin being associated with the clay, with none detected in the water or on the sides of the container.

\subsection{Long-term (14 day) flocculation study}

The fate of $K$. brevis cells and PbTx-2 over a 14 day period following clay flocculation is summarized in Fig. 1 for cell counts and Fig. 2 for brevetoxin concentrations. Cell counts had to be monitored in control as well as experimental cultures because of continued growth, increasing the number of cells and amount of toxin throughout the 14-day study period. The mean cell concentration for all cultures immediately prior to

Table 1

Removal of brevetoxins from $K$. brevis culture by clay flocculation ${ }^{\mathrm{a}}$

\begin{tabular}{|c|c|c|c|c|c|}
\hline \multirow[t]{2}{*}{ Initial concentration } & \multirow[t]{2}{*}{ Flocculant } & \multicolumn{4}{|c|}{$\operatorname{PbTx}-2(\mu \mathrm{g}$ per sample) } \\
\hline & & Control & Water & Clay & Percentage on clay \\
\hline \multicolumn{6}{|l|}{ Whole cells } \\
\hline $5.3 \times 10^{6} / 1$ & Clay & $141 \pm 41$ & $2.9 \pm 0.9$ & $151 \pm 5.6$ & $98 \pm 2$ \\
\hline $4.1 \times 10^{6} / 1$ & Clay & $135 \pm 54$ & $0.5 \pm 0.4$ & $245 \pm 69$ & 100 \\
\hline $9.8 \times 10^{6} / 1$ & Clay & $455 \pm 143$ & $49 \pm 32$ & $726 \pm 241$ & $92 \pm 6$ \\
\hline $8.7 \times 10^{6} / 1$ & Clay & $431 \pm 134$ & $0.6 \pm 0.5$ & $545 \pm 141$ & $99 \pm 1$ \\
\hline $5.5 \times 10^{6} / 1$ & Clay + PAC & $135 \pm 39$ & $1.9 \pm 2.1$ & $152 \pm 33$ & $99 \pm 3$ \\
\hline \multicolumn{6}{|l|}{ Lyzed cells } \\
\hline $5.0 \times 10^{6} / 1$ & Clay & $55.4 \pm 2.5$ & $13.7 \pm 2.1$ & $38.8 \pm 6.5$ & $74 \pm 8$ \\
\hline $5.0 \times 10^{6} / 1(0.51)$ & Clay & $28.7 \pm 1.6$ & $13.7 \pm 5.1$ & $25.8 \pm 5.3$ & $65 \pm 10$ \\
\hline $1.0 \times 10^{6} / 1(0.51)$ & Clay + PAC & 5.8 & $<^{\mathrm{b}}$ & $5.3 \pm 0.3$ & 100 \\
\hline
\end{tabular}

${ }^{\mathrm{a}}$ Clay flocculation with $0.25 \mathrm{~g}$ (dry weight) clay/l in 31 of culture, and with a combination of $0.25 \mathrm{~g}$ clay $+0.04 \mathrm{~g}$ PAC/1; the K. brevis culture samples contained approximately $5 \times 10^{6}$ and $10 \times 10^{6}$ cells/l; total PbTx-2 (sum of intra-cellular and extra-cellular toxins) $\mu \mathrm{g}$ per sample, $n=3$, mean \pm S.D.

${ }^{\mathrm{b}}$ The sign $<$ indicates less than the lower limit of detection, $0.3 \mu \mathrm{g}$ per sample. 


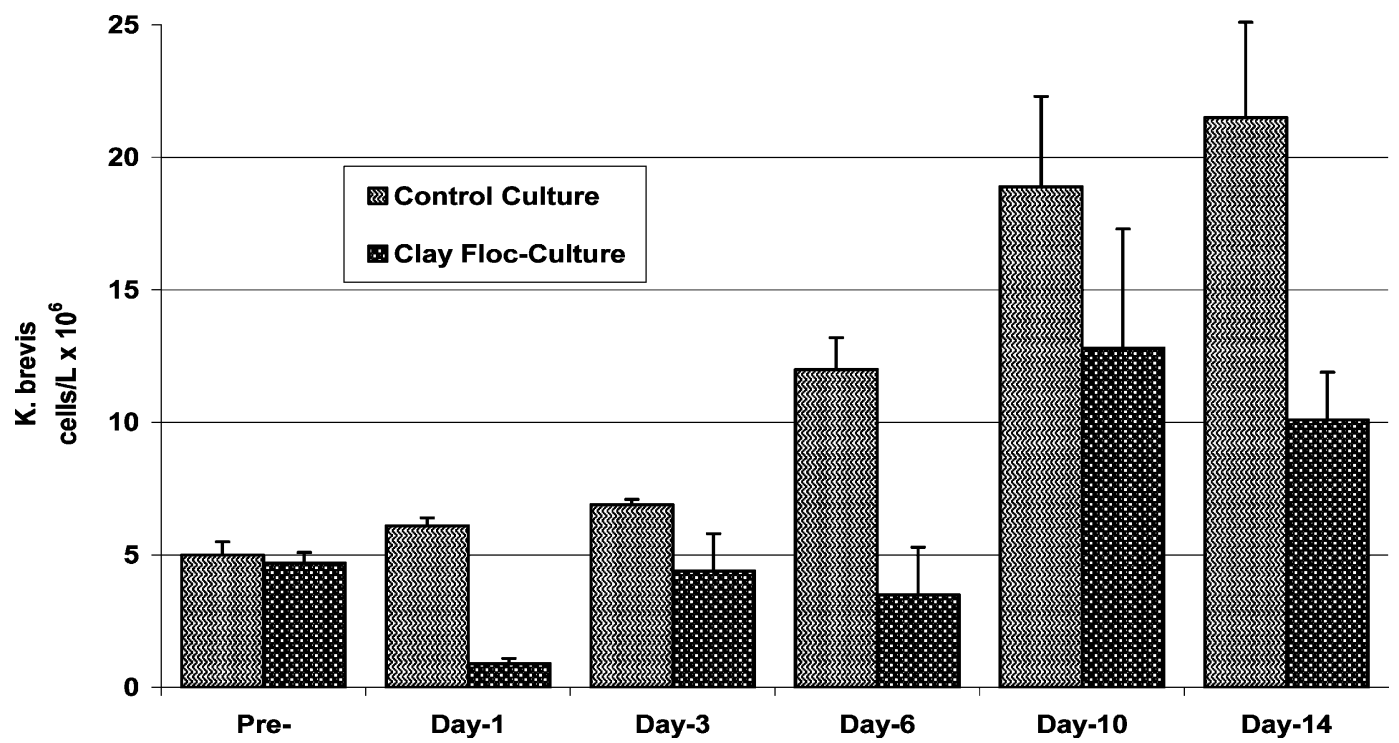

Fig. 1. Changes in K. brevis cell concentrations (cells/ $\times 10^{6}$ ) in water from laboratory culture (control) and in water from clay-flocculated culture throughout a 14-day period: initial cell counts, $5 \times 10^{6}$ cells/l, mean and S.D., $n=3$.

clay flocculation was $5.16 \times 10^{6}$ cells/l (Fig. 1). The percent reduction of $K$. brevis cells from the water column one day after flocculation was $85 \%$ (reduction from $5 \times 10^{6}$ cells/l to $<1 \times 10^{6}$ cells/l), showing a significant removal of cells from the water column. Control cultures continued to grow throughout the study period, increasing from the initial $5 \times 10^{6}$ cells/ to more than $25 \times 10^{6}$ cells/l at Day 14. Following

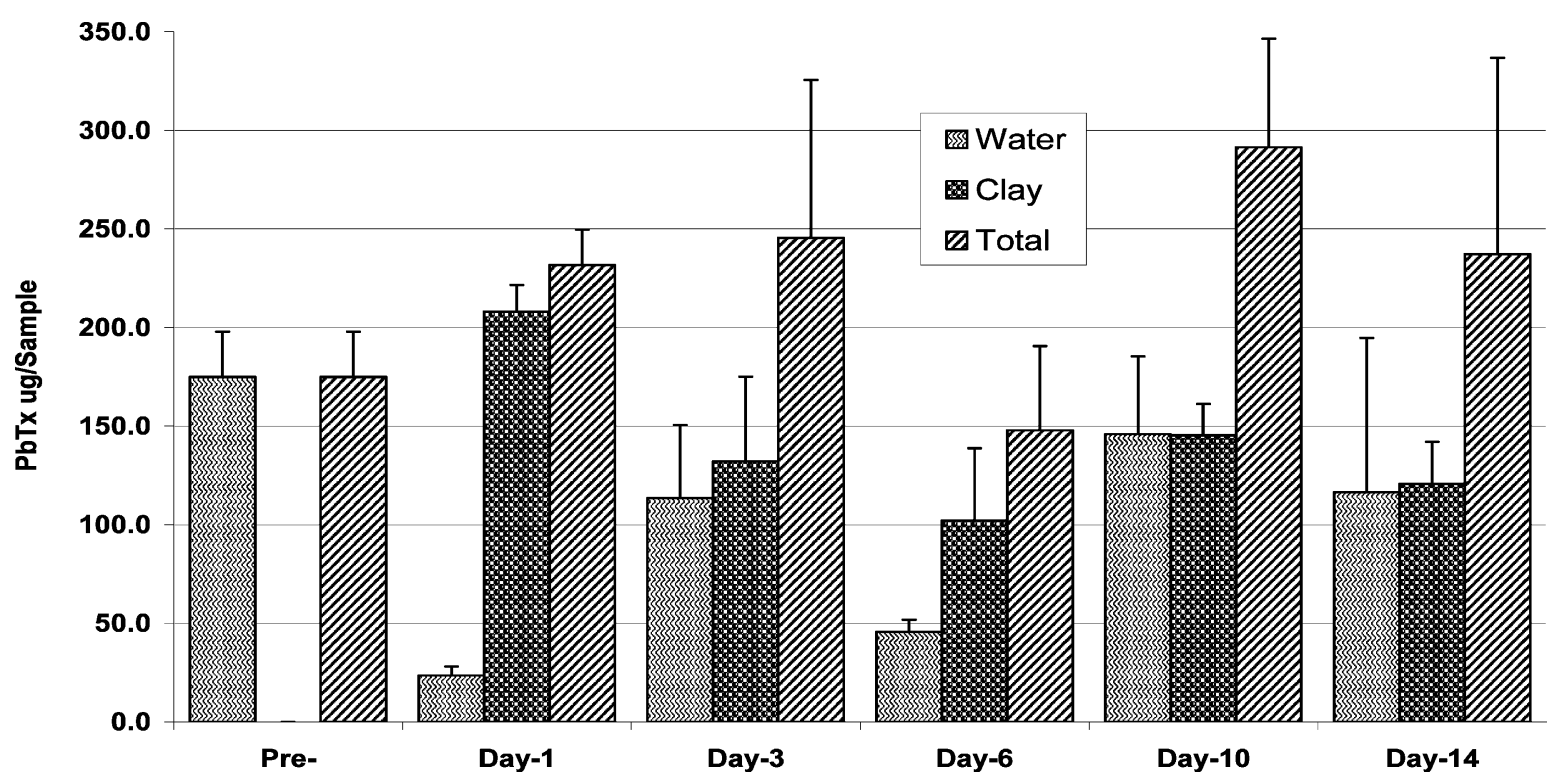

Fig. 2. Changes in brevetoxin PbTx-2 concentration ( $\mu$ g per sample) in water and clay, and total (water + clay) for 14 days following clay flocculation of $K$. brevis cells in laboratory culture: mean and S.D., $n=3$. 
flocculation, cell counts in the water above the clay increased throughout the experiment, doubling in concentration from the initial $5 \times 10^{6}$ cells/l to about $10 \times$ $10^{6}$ cells/l at Day 14.

The concentration of brevetoxin in water and clay floc is shown in Fig. 2. Only PbTx-2 was recovered in sufficient quantity for quantitation by HPLC-UV analysis. One day after clay flocculation, the ratio of toxin associated with the clay floc relative to toxin remaining in the water column was approximately 9:1. At 3 days after flocculation, the ratio of toxin in clay:water was approximately $1: 1$. The increase in water-borne toxin from Day 1 to $3(115 \pm 23 \mu \mathrm{g})$ is associated with the reduction of toxin $(86 \pm 48 \mu \mathrm{g})$ in the flocculated clay. This, along with the increase in resuspended $K$. brevis cells (Fig. 1), indicates that the reappearance of toxin in the water column was primarily due to intra-cellular toxin associated with resuspension and continued reproduction of $K$. brevis cells as described above. Except for Day 6 when an anomalous drop in water-borne toxin was observed, the ratio of PbTx-2 in clay and water remained fairly constant throughout the 14-day study, with no significant difference observed among the concentrations of PbTx-2 in water and in clay among Days 3, 10 and 14. Unfortunately, the range of results was very large from the Day 14 triplicate experimental cultures $(58.8-205.6 \mu \mathrm{g}$ per sample), inhibiting our ability to interpret the 14 day trend in toxin fate. The high number $(205.6 \mu \mathrm{g})$ indicates a continued increase in toxin content, as would be expected from the increase in $K$. brevis cells, whereas the low number would indicate an inhibition of toxin production, or a loss of toxin.

\section{Discussion}

\subsection{Short-term (3-4 h) flocculation study}

Results of the short-term flocculation study showed that $0.25 \mathrm{~g} / \mathrm{l}$ IMC-P2 clay added as slurry was very efficient at removing brevetoxin from culture medium containing intact $K$. brevis cells at concentrations ranging from $5 \times 10^{6}$ to $10 \times 10^{6}$ cells/l. The addition of the flocculant, PAC, yielded no significant improvement in toxin removal because the clay by itself removed $>95 \%$ of $\mathrm{PbTx}-2$ from the water. This success for clay removal of brevetoxin is probably because most of the PbTx-2 was intra-cellular and thus was removed in association with the flocculated $K$. brevis cells. It is important to note, however, that the clay was not as efficient at removing extra-cellular toxin $(65-75 \%)$, indicating that toxin released from cells by ultrasonic lysing was not as readily sequestered and flocculated with the clay as was intra-cellular toxin associated with whole cells. Nevertheless, a significant amount of dissolved toxin was removed by the clay, suggesting that one of the major impacts from $K$. brevis red tides (toxic aerosols), could be alleviated using clay, as discussed further below.

During this study, the clay was added to the water surface and allowed to sink slowly, without mixing or stirring. Although this process has been shown here to be efficient for removing phytoplankton-size particles, the removal of extra-cellular brevetoxin molecules by adsorption to clay floc might well be enhanced in static, laboratory experiments by vigorous shaking to increase physical contact between the clay and toxin molecules. In natural waters, normal currents and wind mixing might should facilitate dissolved toxin removal in this regard.

\subsection{Long-term (14 day) flocculation study}

The long-term flocculation study, utilizing intact $K$. brevis cells, provided an opportunity for viable $K$. brevis cells to recover after flocculation and continue to reproduce. Comparison of viable $K$. brevis cells in cultures following clay flocculation with control cultures to which no clay was added, revealed that after 14 days, the flocculated cultures contained about $40 \%$ of the number of cells found in the control samples. This indicates that clay effectively reduced the number of cells, but did not terminate cell growth. These results are consistent with findings of Sengco et al. (2001) who demonstrated that cells can survive and recover from clay flocculation using similar concentrations of clay and $K$. brevis cells.

Clay removed K. brevis cells and $90 \%$ of the brevetoxin (presumably most as intra-cellular toxin) from the water 1 day after clay flocculation. At Day 14, the clay floc contained $121 \pm 21 \mu \mathrm{g}$ toxin, which was about $43 \%$ of the amount of toxin on the clay at Day 1 (208 $\pm 13 \mu \mathrm{g}$ toxin), reflecting disappearance of toxin from the flocculated clay over time. Previous studies have shown the reduction of $\mathrm{PbTx}-2$ to $\mathrm{PbTx}-3$ as an 
initial step in toxin degradation, however, generation of PbTx-3 was not observed in these samples. These results indicate that reduction in toxin concentration on the clay from Day 1 to 14 was probably due to the escape of viable cells, with possibly some degradation of the toxin to metabolites other than PbTx-2. Further studies are underway to assess the fate of toxins and degradation products associated with the clay floc. We note also that these cell and toxin removal data are only for a single clay application, whereas it is likely that several treatments will be needed for blooms in natural waters (e.g., Na et al., 1997).

Looking to field applications of clay during K. brevis blooms, the adsorption of extra-cellular brevetoxins onto clay could reduce the impact of brevetoxins on fish by inhibiting toxin transport through the gill membrane. Toxin adsorption to clay also could reduce the formation of toxin-containing marine aerosol by inhibiting bubble-mediated transport of dissolved toxins to the sea-air interface and incorporation into marine aerosol in association with jet drops from bursting bubbles (Pierce et al., 1990, 2003). An intriguing unknown is the extent to which fish kills are caused by dissolved brevetoxins that accumulate through time in the water column, as opposed to freshly-released toxins as intact cells encounter gill surfaces. In the former instance, removal of dissolved toxins with low doses of clay (lower than might be needed to remove significant numbers of intact cells) might reduce dissolved toxin concentrations sufficiently to reduce or eliminate fish kills and irritating toxin aerosols, especially in open waters where natural turbulence would enhance interactions between the toxin molecules and the clays. These and related issues are currently under investigation.

\section{Conclusions}

The addition of phosphatic clay to seawater cultures was shown to be an effective means for removing cells and toxins of the harmful alga, K. brevis. Clay added as a slurry at the rate of $0.25 \mathrm{~g}$ clay/l was observed to remove $97 \%$ of brevetoxins associated with live cells (intra-cellular toxins), and $70 \%$ of toxins remaining in solution after the $K$. brevis cells were ruptured (extra-cellular toxins), within $4 \mathrm{~h}$ after addition of the clay. Use of the flocculant, PAC, in addition to clay improved the removal of extra-cellular toxins from culture media. The fate of brevetoxins in association with the flocculated clay was followed over a 14-day period to assess the long-term effectiveness of the clay flocculation process. These results showed that some of the flocculated toxin was released back into the water along with revitalized $K$. brevis cells that escaped from the clay floc and continued to replicate over time. At 14 days after clay flocculation, the toxin content of the clay-treated cultures remained $<50 \%$ of the toxin content in controls. These results highlight the effectiveness of clay treatment for reducing brevetoxin concentrations in the water column, both within intact cells and dissolved in the water column. Further work is clearly needed to better understand the fate and effects of flocculated cells and toxins, especially to benthic communities. Potential negative impacts in the benthos would then have to be balanced against the corresponding reduction in negative impacts in the water column (e.g., fewer fish kills, less toxin in aerosols).

\section{Acknowledgements}

This work was supported by Florida Fish and Wildlife Conservation Commission Contracts MR273, 19013 (Mote), 99157 and S 7701 615727; the Cove Point Foundation; the Sholley Foundation; S.T.A.R.T. (Solutions to Avoid Red Tides), NOAA Grant NA16OP2793 and US EPA Grant CR827090. This is Contribution number 10678 from the Woods Hole Oceanographic Institution. Phosphatic clay was graciously provided by the International Mining Corp. Bartow, Florida, and polyaluminum chloride was provided by Cytec Industries.

\section{References}

Anderson, D.M., 1997. Turning back the harmful red tide. Nature 388, 513-514.

Anderson, D.M., Garrison, D.J., 1997. The ecology and oceanography of harmful algal blooms. Limnol. Oceanogr. 42, 1009-1305.

Baden, D.G., Flemming, L.A., Bean, J.A. (1995). Marine toxins. In: DeWolf, F.A. (Ed.), Handbook of Clinical Neurology, vol. 21, Elsevier, New York, USA, pp. 1-34.

Barwood, H.L. (1982). Mineralogy and chemistry of phosphatic clays. In: Clark, S.W. (Ed), Phosphatic Clay Workshop, FIPR 
Publ. No. 02-020-012, Bartow, Florida. Florida Institute of Phosphate Research, Bartow, pp. 30-41.

Boesch, D.F., Anderson, D.M., Horner, R.A., Shumway, S.E., Tester, P.A., Whitledge, T.E. (1997). Harmful Algal Blooms in Coastal Waters: Options for Prevention, Control and Mitigation, vol. 46. NOAA Coastal Ocean Program Decision Analysis Series No. 10. NOAA Coastal Office, Sliver Spring, MD, pp. 201-261.

Bromwell, L.G. (1982). Physico-chemical properties of Florida phosphatic clays. Florida Institute of Phosphate Research, Bartow. FIPR/PUB-02-003-020.

Dickey, R., Jester, E., Granade, R., Mowdy, D., Moncrieff, C., Rebarchik, D., Robl, M., Musser, S., Poli, M., 1999. Monitoring brevetoxins during a $G$. breve red tide: comparison of a sodium channel specific cytotoxicity assay and mouse bioassay for determination of neurotoxic shellfish toxins in shellfish extracts. Nat. Toxins 7, 157-165.

Duagbjerg, N., Hansen, G., Larsen, J., Moestrup, O., 2001. Phylogeny of some of the major genera of dinoflagellates based on ultrastructure and partial LSU R-DNA sequence data: including the erection of three new genera of unarmored dynoflagellates. Phycologia 39 (4), 302-317.

Guillard, R.R.L. (1973). Division rates. In: Stein, J.R. (Ed.), Handbook of Phycological Methods. Cambridge, pp. 289-311.

Guillard, R.R.L., Hargraves, P.E., 1993. Stichochrysis immobilis is a diatom, not a chrysophyte. Phycologia 32, 234-236.

Na, G.H., Choi, W.J., Chun, Y.Y. (1997) Cochlodinium red tide control with loess suspension. In: Reguera, B., Blanco, J., Fernandez, M.L., Wyatt, T. (Eds.), Proceedings of the Eighth International Conference on Harmful Algae, Vigo Spain, pp. 227-228.

Pierce, R.H., Kirkpatrick, G.J., 2001. Innovative techniques for harmful algal toxin analysis. Environ. Toxicol. Chem. 20 (1), $107-114$.

Pierce, R.H., Henry, M.S., Proffitt, L.S., Hasbrouck, P.A. (1990). Red tide toxin (brevetoxin) enrichment in marine aerosol. In: Graneli, E., Sundstrom, B., Elder, L., Anderson, D.M. (Eds.), Toxic Marine Phytoplankton, Elseiver, Amsterdam, pp. 397-402.

Pierce, R.H., Henry, M.S., Proffitt, L.S., deRosset, A.J., 1992. Evaluation of solid sorbents for the recovery of polyether toxins (brevetoxins) in seawater. Bull. Environ. Contam. Toxicol. 49, 479-484.

Pierce, R.H., Henry, M.S., Blum, P., Payne, S. (2001). Gymnodinium breve toxins without cells: Intra-cellular and extra-cellular toxins. In: Hallegraeff, G.M., Blackburn, S.I., Bolch, C.J., Lewis, R.J. (Eds.), Harmful Algal Blooms 2000. IOC of UNESCO, Paris, pp. 421-424.

Pierce, R.H., Henry, M.S., Blum, P.C., Lyons, J., Cheng, Y.S., Yazzie, D., Zhou, Y., 2003. Brevetoxin concentrations in marine aerosol: Human exposure levels during a Karenia brevis harmful algal bloom. Bull. Environ. Contam. Toxicol. 70 (1), 161-165.

Poli, M., Mende, T.J., Baden, D., 1986. Brevetoxins, unique activators of voltage-sensitive sodium channels bind to specific sites in rat synaptosomes. Mol. Pharmacol. 30, 129-135.

Sengco, M.R., Li, A., Kulis, K., Anderson, D.M., 2001. Removal of red- and brown-tide cells using clay flocculation. I. Laboratory culture experiments with Gymnodinium breve and Aureococcus anophagefferens. Mar. Ecol. Prog. Ser. 210, 41-53.

Shimizu, Y., Gupta, S., Hong-Nong, C. (1990). Biosynthesis of red tide toxins. In: Hall S., Strichartz, G., (Eds.), Marine Toxins Origin, Structure and Molecular Pharmacology. Am. Chem. Soc., Washington, DC, pp. 21-28.

Shirota, A., 1989. Red tide problem and countermeasures (Part 2). Int. J. Aquat. Fish. Technol. 1, 195-293.

Smayda, T.J. (1990). Novel and nuisance phytoplankton blooms in the sea: evidence for a global epidemic. In: Proceedings from the Fourth International Conference on Toxic Marine Phytoplankton, Lund, Sweden, June 26-30, 1989, pp 29-40.

Steidinger, K.A., Baden, D.G. (1983). Toxic marine dinoflagellates. In: Spector, L. (Ed.), Dinoflagellates. Academic Press, New York, USA, pp. 201-261.

Tester, P., Steidinger, K.A., 1997. Gymnodinium breve red tide blooms: initiation, transport and consequences of surface circulation. Limnol. Oceanogr. 45, 1039-1051.

Yu, Z., Zou, J.Z., Ma, X., 1994. Application of clays to removal of red tide organisms. II. Coagulation of different species of red tide organisms with montmorillonite and effect of clay pretreatment. Chin. J. Oceanol. Limnol. 12, 316-324.

Yu, Z., Zou, J.Z., Ma, X., 1995. Application of clays to removal of red tide organisms. III. The coagulation of kaolin on red tide organisms. Chin. J. Oceanol. Limnol. 13, 62-70. 